\title{
Continuous flow photocyclization of stilbenes - scalable synthesis of functionalized phenanthrenes and helicenes
}

\author{
Quentin Lefebvre, Marc Jentsch and Magnus Rueping*
}

\author{
Full Research Paper \\ Address: \\ Institute of Organic Chemistry, RWTH Aachen University, Landoltweg \\ 1, D-52074 Aachen, Germany \\ Email: \\ Magnus Rueping ${ }^{*}$ - magnus.rueping@rwth-aachen.de \\ ${ }^{*}$ Corresponding author \\ Keywords: \\ continuous-flow reactor; flow chemistry; helicenes; light-driven \\ cyclization reaction; photocyclization; stilbenes
}

Open Access

\author{
Beilstein J. Org. Chem. 2013, 9, 1883-1890. \\ doi:10.3762/bjoc. 9.221 \\ Received: 12 July 2013 \\ Accepted: 14 August 2013 \\ Published: 17 September 2013 \\ This article is part of the Thematic Series "Chemistry in flow systems III". \\ Guest Editor: A. Kirschning \\ (c) 2013 Lefebvre et al; licensee Beilstein-Institut. \\ License and terms: see end of document.
}

\begin{abstract}
A continuous flow oxidative photocyclization of stilbene derivatives has been developed which allows the scalable synthesis of backbone functionalized phenanthrenes and helicenes of various sizes in good yields.
\end{abstract}

\section{Introduction}

Phenanthrenes are versatile intermediates toward polycyclic aromatic hydrocarbons which are relevant for materials sciences, as well as toward helicenes, an intriguing class of molecules which show remarkable chiroptical properties due to their helical pitch. The rapidly expanding field of application of helicene-like molecules in materials sciences and optics demands the development of scalable and flexible syntheses [1-5].

Following the pioneering examples of Scholz [6] and Martin [7] in 1967, the photocyclization of stilbene derivatives under UV-light irradiation is now a classical method for the synthesis of phenanthrenes and helicene-like molecules [8]. However, the scalability of these reactions is limited by the required low concentration $\left(\sim 10^{-3} \mathrm{~mol} \cdot \mathrm{L}^{-1}\right)$ and usually long reaction times $(>20 \mathrm{~h})$. Therefore, most of the applications of this method are limited to small scale $(<0.5 \mathrm{mmol})$, making it unsuitable for gram-scale synthesis of helicene-like molecules [9-12]. Much effort has devoted to the development of alternative pathways toward helicenes, but most approaches require lengthy syntheses of the precursors [13-15]. It should be noted that an elegant semi-one-pot procedure for the synthesis of phenanthrenes from styrenes and benzene was recently reported [16]. However, also in this case, the scale of the reaction is limited by the size of the photoreactor.

Reactions in flow are typically faster and cleaner compared to the corresponding reactions in batch. A flow setup is particu- 
larly well-suited for photo-catalysed reactions as the efficiency of the transformation is no longer related to the scale [17-21]. Therefore, the development of an efficient protocol for the photocyclization of stilbene derivatives in flow would be of great interest. A recent contribution described the flow-synthesis of [5]helicene under visible light in the presence of a sensitizer [22], but, to the best of our knowledge, no reports on broadly applicable light-induced oxidative photocyclizations in flow are known. Herein, we report the first photocyclization of polysubstituted olefins using a continuous flow process and discuss advantages and limitations of this new protocol. Generally, the oxidative photodehydrogenation of $E$-stilbene results in the formation of phenanthrene (Scheme 1). In this reaction the $E$-olefin (or a $E / Z$ mixture of the olefin) is photoisomerised to the reactive $Z$-olefin, which undergoes photocyclization. The corresponding dihydrophenanthene is subsequently oxidized with iodine to give the desired phenanthrene and HI, which can be quenched by propylene oxide or THF.

\section{Results and Discussion}

In order to accomplish a first general photocyclization we started with the photocyclization of stilbene. Optimization of the reaction conditions in a small flow setup $(5 \mathrm{~mL}$ FEP tubing, $150 \mathrm{~W}$ UV-lamp) is presented in Table 1. Although both THF and propylene oxide showed good ability to quench HI, we choose THF as additive due to its lower cost, volatility and toxicity $[23,24]$. Under the optimized conditions, $E$-stilbene (1a) could be converted to phenanthrene (2a) in 95\% NMR yield with a retention time of $83 \mathrm{~min}$ (Table 1, entry 5).

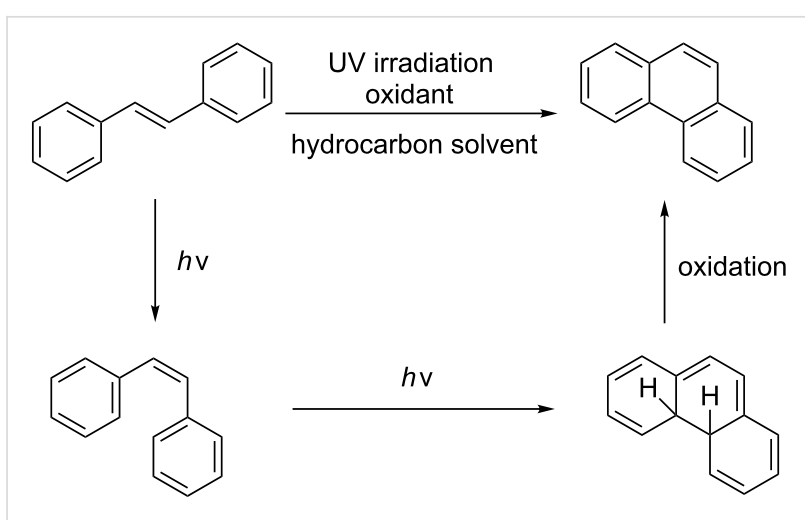

Scheme 1: Photocyclization of stilbene to phenanthrene.

The flow-reactor setup used for the optimization (Table 1) is shown in Figure 1. UV-transparent ethylene propylene copolymer capillary (FEP, outer/inner diameter $1 / 0.5 \mathrm{~mm}$, total volume $5 \mathrm{~mL}$ ) was tightly wrapped around the water-cooling unit (Duran glass) of a high-pressure mercury lamp (TQ 150, UV-Consulting Peschl). Further optimization and scope was performed with a similar setup using a bigger capillary (FEP, outer/inner diameter $4 / 2 \mathrm{~mm}$, total volume $24 \mathrm{~mL}$ ). For the sake of safety and to enhance the efficiency of irradiation by reflection, the setup was placed into a laboratory Dewar flask and the exposed parts of the setup were covered with aluminium foil (the temperature inside the Dewar was determined to be around $40{ }^{\circ} \mathrm{C}$ ). The reaction mixture was injected into the system using a syringe pump and collected at the outlet of the tubing into a round bottom flask.<smiles>C(=C/c1ccccc1)\c1ccccc1</smiles>

1a (concentration)

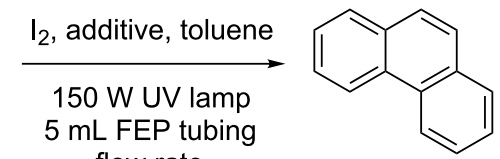

$2 a$

\begin{tabular}{|c|c|c|c|c|}
\hline Entrya & $\begin{array}{l}\text { Additive } \\
\text { (20 equiv) }\end{array}$ & $\begin{array}{c}\text { Concentration } \\
(\mathrm{mol} / \mathrm{L})\end{array}$ & $\begin{array}{l}\text { Flow rate } \\
(\mathrm{mL} / \mathrm{min})\end{array}$ & Yield $^{\mathrm{b}}(\%)$ \\
\hline 1 & propylene oxide & 0.01 & 0.06 & 33 \\
\hline 2 & THF & 0.01 & 0.04 & 37 \\
\hline 3 & THF & 0.01 & 0.02 & 44 \\
\hline 4 & propylene oxide & 0.001 & 0.06 & 99 \\
\hline 5 & THF & 0.002 & 0.06 & 95 \\
\hline 6 & cyclohexene & 0.002 & 0.06 & $-^{\mathrm{c}}$ \\
\hline 7 & THF & 0.002 & 0.08 & 68 \\
\hline 8 & THF & 0.003 & 0.06 & 50 \\
\hline
\end{tabular}

a1.1 equiv of iodine were used. The solvent was dry toluene. ${ }^{b}$ Determined by ${ }^{1} \mathrm{H}$ NMR using mesitylene as internal standard. ${ }^{\mathrm{C}}$ Mainly $Z$-stilbene was observed. 


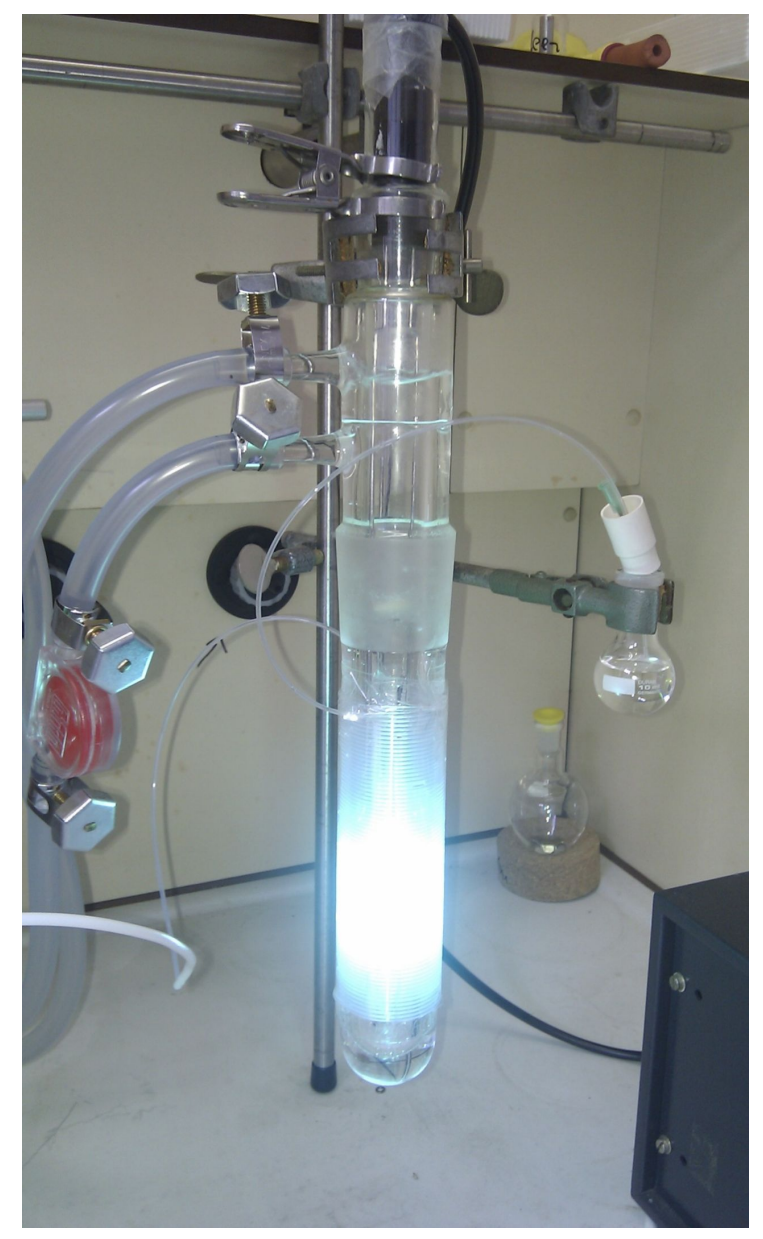

Figure 1: Flow-reactor setup used in the optimization study.

Additionally, we developed a 5-fold bigger setup to enhance the throughput (Table 2). Slightly longer retention times were required, and degassed toluene provided better yields. Finally,

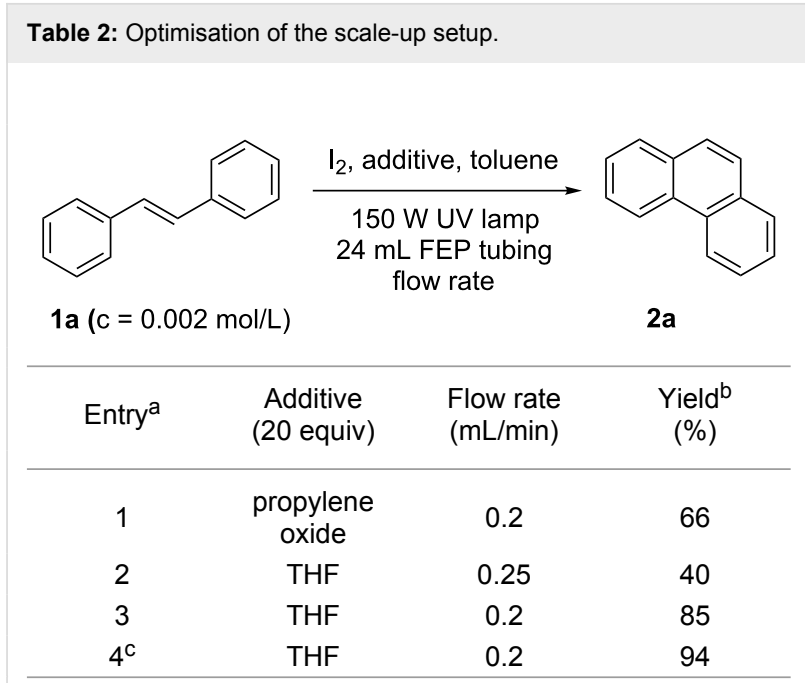

a1.1 equiv of iodine were used. Dry toluene was used as solvent. ${ }^{b}$ Determined by ${ }^{1} \mathrm{H}$ NMR using mesitylene as internal standard. ${ }^{\mathrm{C}}$ Degassed toluene was used.

phenanthrene (2a) was obtained in $94 \%$ yield when a flow rate of $0.2 \mathrm{~mL} / \mathrm{min}$ (retention time of $120 \mathrm{~min}$ ) was applied (Table 2, entry 4).

With the optimised conditions in hand, we explored the scope of the reaction. Although photocyclization of disubstituted olefins in batch was well documented in the literature, only few cases of photocyclization of tri- and tetrasubstituted olefins were reported [16,25]. Therefore, we decided to demonstrate our methodology on both di- and trisubstituted olefins (Table 3). We disclose here the first photocyclization of trisubstituted olefins in flow, giving access to backbone-functionalised phenanthrene derivatives.

Table 3: Scope of the photocyclization of stilbene derivatives in continuous flow to give substituted phenanthrenes.<smiles>[R1]/C(=C\c1ccc([R])c([R])c1)c1ccc([R])cc1</smiles>

$1(c=0.002 \mathrm{~mol} / \mathrm{L})$

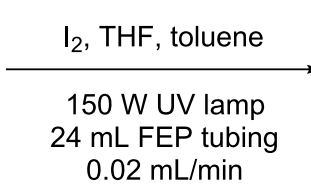

$0.02 \mathrm{~mL} / \mathrm{min}$<smiles>[R]c1ccc2c([R])cc3cc([R])c([R])cc3c2c1</smiles>

2

Entry ${ }^{\mathrm{a}}$


Table 3: Scope of the photocyclization of stilbene derivatives in continuous flow to give substituted phenanthrenes. (continued)

2<smiles>Cc1ccc(/C=C/c2ccccc2)cc1</smiles>

3<smiles>Brc1ccc(C=Cc2ccccc2)cc1</smiles>

4<smiles>COc1ccc(/C=C\c2ccc(C)cc2)cc1</smiles>

5<smiles>Brc1ccc(C=Cc2cccnc2)cc1</smiles>

6<smiles>CC(=Cc1ccc(Br)cc1)c1ccccc1</smiles>

7<smiles>CC(=Cc1ccc(Br)cc1)c1ccc(Br)cc1</smiles>

8

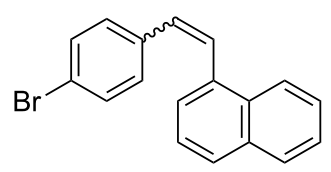<smiles>Cc1ccc2ccc3ccccc3c2c1</smiles>

2b<smiles>Brc1ccc2ccc3ccccc3c2c1</smiles>

61

2c<smiles>COc1ccc2ccc3ccc(C)cc3c2c1</smiles>

77

2d<smiles>Brc1ccc2ccc3cccnc3c2c1</smiles><smiles>Brc1ccc2ccc3cnccc3c2c1</smiles>

$2 \mathrm{e}$ and $2 \mathrm{e}^{\prime}$<smiles>Cc1cc2ccc(Br)cc2c2ccccc12</smiles>

$2 f$<smiles>Cc1cc2ccc(Br)cc2c2cc(Br)ccc12</smiles>

2g<smiles>Brc1ccc2ccc3c4ccccc4ccc3c2c1</smiles>

$2 \mathrm{~h}$

aReaction conditions: 1.1 equiv iodine, 20 equiv THF, UV-light, $2 \mathrm{~h}$ retention time. ${ }^{b}$ Yield after chromatography.

We choose stilbenes with bromide and methyl substituents, as the latter can be used in subsequent oxidation, deprotonation, and radical addition reactions, whereas the former opens access to various functional groups via lithium-halogen exchange or cross-coupling chemistry. Methoxy groups were also tolerated, but nitro- and amino groups containing stilbenes showed low conversion or decomposition. Meta-substituted substrates gave inseparable regioisomers, and ortho-substitution led to low conversion. In the case of substrate 1e, a separable 1:1 mixture of regioisomers $2 \mathrm{e}$ and $\mathbf{2 e}$ ' was obtained (Table 3 , entry 5 ). 
However, generally a series of stilbenes reacted smoothly to the desired phenantrenes in good yields.

Recently, an unexpected synthesis of [4] helicenes was disclosed [26]. However, no 2-substituted [4]helicenes were synthesised using this method. Therefore, we investigated the photocyclization of the corresponding stilbene derivatives in our flow setup, for both di- and trisubstituted olefins (Table 4).

Again, various functional groups were tolerated in the flow photocyclization. Interestingly, if substrate $\mathbf{1 k}$ was irradiated in toluene a single regioisomer $\mathbf{2 k}$ was isolated (Table 4, entry 3), whereas the reaction in acetonitrile resulted in a separable 1:1 mixture of regioisomers $\mathbf{2} \mathbf{k}$ and $\mathbf{2} \mathbf{k}^{\prime}$ (Table 4, entry 4).

Finally, we decided to apply our photo-flow methodology in the synthesis of functionalised [5]helicenes and [6]helicenes. We identified 3-acetyl-9,10-dimethoxyphenanthrene [27] as a powerful intermediate for the two-step synthesis of functionalisable helically chiral products. As shown in Scheme 2, Wittig or Horner-Wadsworth-Emmons reactions gave the corresponding olefins 10-r in good yields, which were subjected to photocy-

Table 4: Scope: synthesis of [4]helicenes by photocyclization in flow.

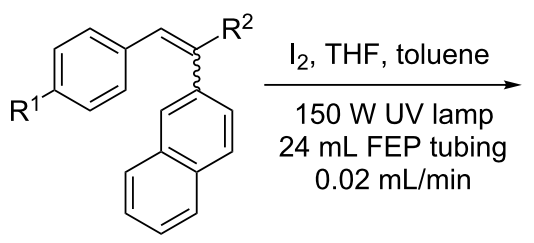

$1(c=0.002 \mathrm{~mol} / \mathrm{L})$<smiles>[R]c1ccc2cc([R])c3ccc4ccccc4c3c2c1</smiles>

2

\begin{tabular}{|c|c|c|c|}
\hline Entry ${ }^{a}$ & Substrate & Product (2) & $\begin{array}{c}\text { Yield }^{b} \\
(\%)\end{array}$ \\
\hline
\end{tabular}

1<smiles>Fc1ccc(C=Cc2ccc3ccccc3c2)cc1</smiles>

2<smiles>COc1ccc(C=Cc2ccc3ccccc3c2)cc1</smiles>

3<smiles>CC(=O)c1ccc(/C=C/c2cnc3ccccc3c2)cc1</smiles>

$4^{c}$<smiles>CC(=O)c1ccc(/C=C/c2cnc3ccccc3c2)cc1</smiles><smiles>Fc1ccc2ccc3ccc4ccccc4c3c2c1</smiles>

$2 \mathbf{i}$<smiles>COc1ccc2ccc3ccc4ccccc4c3c2c1</smiles>

$2 \mathrm{j}$<smiles>CC(=O)c1ccc2ccc3cnc4ccccc4c3c2c1</smiles>

2k<smiles>CC(=O)c1ccc2ccc3cnc4ccccc4c3c2c1</smiles><smiles>CC(=O)c1ccc2ccc3cc4ccccc4nc3c2c1</smiles>

$40 / 41$

$2 k$ and $2 k^{\prime}$ 
Table 4: Scope: synthesis of [4]helicenes by photocyclization in flow. (continued)

5<smiles>CC(=Cc1ccc(Br)cc1)c1ccc2ccccc2c1</smiles>

6<smiles>C/C(=C/c1ccc(C)cc1)c1ccc2ccccc2c1</smiles>

7

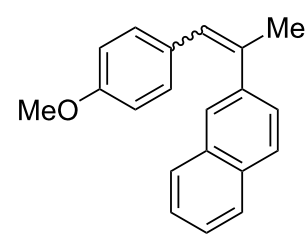<smiles>Cc1cc2ccc(Br)cc2c2c1ccc1ccccc12</smiles>

2I<smiles>Cc1ccc2cc(C)c3ccc4ccccc4c3c2c1</smiles>

$2 \mathrm{~m}$<smiles>COc1ccc2cc(C)c3ccc4ccccc4c3c2c1</smiles>

2n

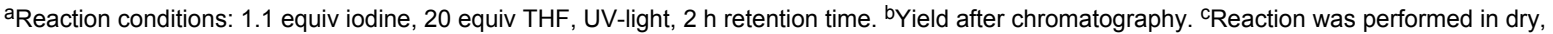
degassed acetonitrile.

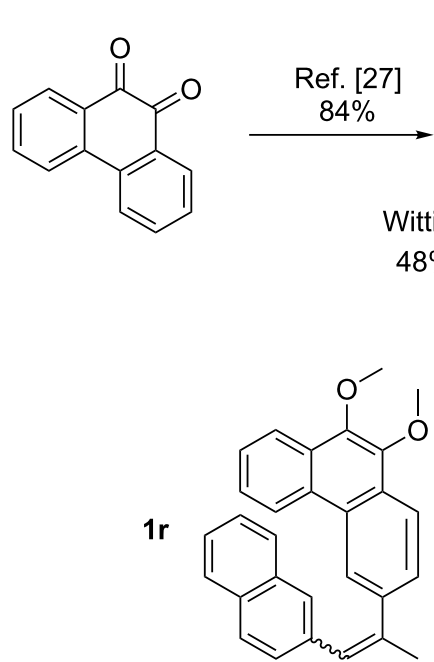<smiles>COc1c(OC)c2ccc3c(C)cc4ccc5ccccc5c4c3c2c2ccccc12</smiles><smiles>COc1c(OC)c2ccc(C(C)=O)cc2c2ccccc12</smiles>

Wittig or HWE<smiles>COc1c(C)cc2ccccc2c1OC</smiles>

$\mathrm{R}=\mathrm{B}: \quad 10,72 \%$

$\mathrm{R}=\mathrm{Me}: \quad$ 1p, $69 \%$

$\mathrm{R}=$ OMe: 1q, $77 \%$
$\mathrm{R}$

Photo-flow ${ }^{\mathrm{a}, \mathrm{b}}$<smiles>COc1c(OC)c2ccc3c(C)cc4ccc(Br)cc4c3c2c2ccccc12</smiles>

2o, $65 \%$

R<smiles>C=C(C)/C(C)=C\c1ccccc1</smiles>

Photo-flow ${ }^{a, b}$<smiles>COc1cc2c3c4c(C)ccc3cc(C)c3ccc(c1OC)c2c3-4</smiles>

$\mathrm{R}=\mathrm{Me}: \quad 2 \mathrm{p}, 58 \%$

$\mathrm{R}=\mathrm{OMe} ： 2 \mathrm{q}, 52 \%$

$2 \mathbf{r} / 2 \mathbf{r}^{\prime}, 75 \%, 1: 1$ ratio

Scheme 2: Photo-flow synthesis of [5]- and [6]helicenes. ${ }^{a}$ For experimental details see Supporting Information File $1 .{ }^{b}$ Reaction conditions: 1.1 equiv iodine, 20 equiv THF, UV-light, $2 \mathrm{~h}$ retention time. 
clization in flow using the optimised conditions for the simpler stilbenes. In the [5]helicene series, in each case only one product was isolated in moderate to good yield. The bromoolefin 10 gave exclusively the desired helicene 2o, but in the case of methyl- and methoxyolefins $\mathbf{1 p}$ and $\mathbf{1 q}$, only the corresponding benzo[ghi]perylenes $\mathbf{2} \mathbf{p}$ and $\mathbf{2 q}$ were observed. Benzo[ghi]perylenes are typical byproducts observed in the photocyclization of [5] helicene-like molecules. Reactions to obtain selectively helicenes or benzo[ghi]perylenes, regardless of the substitution pattern, are still a challenging task. A functionalizable [6] helicene (2r) was obtained along with its ribbonlike regioisomer $\mathbf{2} \mathbf{r}^{\prime}$ in a 1:1 ratio and $75 \%$ combined yield.

In order to demonstrate the utility of the flow process we decided to scale up the synthesis of helical compound $\mathbf{2 0}$. To our delight, we observed that the [5]helicene precursor 10 underwent photocyclization with considerably shorter retention times compared to the standard stilbene derivatives (Scheme 3). Thus, we prepared the [5] helicene derivative 20 with up to 60 $\mathrm{mg} / \mathrm{h}$ (for the full optimisation table, see Supporting Information File 1).<smiles>COc1c(C)c2ccc(/C=C\c3ccc(Br)cc3)cc2c2ccccc12</smiles>

10<smiles>COc1c(OC)c2ccc3ccc4ccc(Br)cc4c3c2c2ccccc12</smiles>

20
Scheme 3: Scale up synthesis of the [5]helicene derivative 20.

\section{Conclusion}

In summary, we have developed a new photo-flow methodology [28-32] for the synthesis of phenanthrenes and helicenes. Although photocyclization of stilbene derivatives was disclosed more than 40 years ago, this is the first report of UV-lightdriven photocyclization in flow. In general phenantrenes as well as [4]-, [5]- and [6]helicenes with different substitution patterns are obtained in good to excellent yields. In addition our first attempts to scale up the flow photocyclization reactions were successful providing the opportunity for multi-gram syntheses.

\section{Supporting Information}

\section{Supporting Information File 1}

Experimental part.

[http://www.beilstein-journals.org/bjoc/content/

supplementary/1860-5397-9-221-S1.pdf]

\section{References}

1. Shen, Y.; Chen, C.-F. Chem. Rev. 2012, 112, 1463-1535. doi:10.1021/cr200087r

2. Gingras, M. Chem. Soc. Rev. 2013, 42, 968-1006. doi:10.1039/c2cs35154d

3. Gingras, M.; Félix, G.; Peresutti, R. Chem. Soc. Rev. 2013, 42, 1007-1050. doi:10.1039/c2cs35111k

4. Gingras, M. Chem. Soc. Rev. 2013, 42, 1051-1095. doi:10.1039/c2cs35134j

5. Moorthy, J. N.; Mandal, S.; Mukhopadhyay, A.; Samanta, S. J. Am. Chem. Soc. 2013, 135, 6872-6884. doi:10.1021/ja312027c See for a recent example of application of a carbohelicene in optics.

6. Scholz, M.; Mühlstädt, M.; Dietz, F. Tetrahedron Lett. 1967, 8, 665-668. doi:10.1016/S0040-4039(00)90569-0

7. Flammang-Barbieux, M.; Nasielski, J.; Martin, R. H. Tetrahedron Lett 1967, 8, 743-744. doi:10.1016/S0040-4039(00)90586-0

8. Liu, L.; Yang, B.; Katz, T. J.; Poindexter, M. K. J. Org. Chem. 1991, 56, 3769-3775. doi:10.1021/jo00012a005

9. Terfort, A.; Görls, H.; Brunner, H. Synthesis 1997, 79-86. doi:10.1055/s-1997-1498

10. Reetz, M. T.; Sostmann, S. J. Organomet. Chem. 2000, 603, 105-109. doi:10.1016/S0022-328X(00)00173-X

11. El Abed, R.; Ben Hassine, B.; Genêt, J.-P.; Gorsane, M.; Marinetti, A. Eur. J. Org. Chem. 2004, 1517-1522. doi:10.1002/ejoc.200300470

12. El Abed, R.; Aloui, F.; Genêt, J.-P.; Ben Hassine, B.; Marinetti, A. J. Organomet. Chem. 2007, 692, 1156-1160. doi:10.1016/j.jorganchem.2006.11.022

13. Stará, I. G.; Alexandrová, Z.; Teplý, F.; Sehnal, P.; Starý, I.; Šaman, D.; Buděšínský, M.; Cvaèka, J. Org. Lett. 2005, 7, 2547-2550. doi:10.1021/ol047311p

14. Míšek, J.; Teplý, F.; Stará, I. G.; Tichý, M.; Šaman, D.; Císařová, I.; Vojtíšek, P.; Starý, I. Angew. Chem. 2008, 120, 3232-3235. doi:10.1002/ange. 200705463 Angew. Chem., Int. Ed. 2008, 47, 3188-3191. doi:10.1002/anie.200705463

15. Weimar, M.; Correa da Costa, R.; Lee, F.-H.; Fuchter, M. J. Org. Lett. 2013, 15, 1706-1709. doi:10.1021/ol400493x

16. Li, H.; He, K.-H.; Liu, J.; Wang, B.-Q.; Zhao, K.-Q.; Hu, P.; Shi, Z.-J. Chem. Commun. 2012, 48, 7028-7030. doi:10.1039/c2cc33100d

17. Matsushita, Y.; Ichimura, T.; Ohba, N.; Kumada, S.; Sakeda, K.; Suzuki, T.; Tanibata, H.; Murata, T. Pure Appl. Chem. 2007, 79, 1959-1968. doi:10.1351/pac200779111959

18. Oelgemöller, M.; Shvydkiv, O. Molecules 2011, 16, 7522-7550. doi:10.3390/molecules16097522

19. Knowles, J. P.; Elliott, L. D.; Booker-Milburn, K. I. Beilstein J. Org. Chem. 2012, 8, 2025-2052. doi:10.3762/bjoc.8.229

20. Oelgemöller, M. Chem. Eng. Technol. 2012, 35, 1144-1152. doi:10.1002/ceat.201200009

21. Shvydkiv, O.; Oelgemöller, M. Microphotochemistry: Photochemical Synthesis in Microstructed Flow Reactors. In CRC Handbook of Organic Photochemistry and Photobiology; Griesbeck, A.; Oelgemöller, M.; Ghetti, F., Eds.; CRC Press: Boca Raton, FL, USA, 2012; pp 125-178.

22. Hernandez-Perez, A. C.; Vlassova, A.; Collins, S. K. Org. Lett. 2012, 14, 2988-2991. doi:10.1021/ol300983b

23. Talele, H. R.; Gohil, M. J.; Bedekar, A. V. Bull. Chem. Soc. Jpn. 2009, 82, 1182-1186. doi:10.1246/bcsj.82.1182

24. Talele, H. R.; Chaudhary, A. R.; Patel, P. R.; Bedekar, A. V. ARKIVOC 2011, No. ix, 15-37. doi:10.3998/ark.5550190.0012.902 
25. Yavari, K.; Moussa, S.; Ben Hassine, B.; Retailleau, P.; Voituriez, A.; Marinetti, A. Angew. Chem. 2012, 124, 6852-6856.

doi:10.1002/anie.201202024

Angew. Chem., Int. Ed. 2012, 51, 6748-6752

doi:10.1002/anie.201202024

26. Truong, T.; Daugulis, O. Chem. Sci. 2012, 4, 531-535.

doi:10.1039/c2sc21288a

27. Wang, D. Z.; Katz, T. J. J. Org. Chem. 2005, 70, 8497-8502.

doi:10.1021/jo0512913

28. Liao, H.-H.; Hsiao, C.-C.; Sugiono, E.; Rueping, M. Chem. Commun. 2013, 49, 7953-7955. doi:10.1039/c3cc43996h

See for recent applications of flow chemistry from our group.

29. Rueping, M.; Vila, C.; Bootwicha, T. ACS Catal. 2013, 3, 1676-1680. doi:10.1021/cs400350j

30. Rueping, M.; Bootwicha, T.; Sugiono, E. Beilstein J. Org. Chem. 2012, 8, 300-307. doi:10.3762/bjoc.8.32

31. Rueping, M.; Bootwicha, T.; Baars, H.; Sugiono, E. Beilstein J. Org. Chem. 2011, 7, 1680-1687. doi:10.3762/bjoc.7.198

32. Rueping, M.; Bootwicha, T.; Sugiono, E. Adv. Synth. Catal. 2010, 352, 2961-2965. doi:10.1002/adsc.201000538

\section{License and Terms}

This is an Open Access article under the terms of the Creative Commons Attribution License

(http://creativecommons.org/licenses/by/2.0), which permits unrestricted use, distribution, and reproduction in any medium, provided the original work is properly cited.

The license is subject to the Beilstein Journal of Organic Chemistry terms and conditions:

(http://www.beilstein-journals.org/bjoc)

The definitive version of this article is the electronic one which can be found at: doi:10.3762/bjoc. 9.221 